\title{
DEE EI/22027-TI
}

101001991

\section{THE COMMONWEALTH OF MASSACHUSETTS \\ DIVISION OF ENERGY RESOURCES}

$\mathrm{DOE} / \mathrm{E}$ I/ $22627--\mathrm{Tl}$

DE9 2005261

\section{FINAL REPORT}

\section{No. 2 Heating Oil/Propane Program}

\section{$1990 / 91$}

\section{DISC $\triangle$ AIMER}

\begin{abstract}
This report was prepared as an account of work sponsored by an agency of the United States Government. Neither the United States Government nor any agency thereof, nor any of their employees, makes any warranty, express or implied, or assumes any legal liability or responsibility for the accuracy, completeness, or usefulness of any information, apparatus, product, or brocess disclosed, or represents that its use would not infringe privately owned rights. Reference herein to any specific commercial product, process, or service by trade name, trademark. manufacturer, of otherwise does not necessarily constitute or imply its endorsement. recommendation. or favoring by the United States Government or any agency thereof. The views and opinions of authors expressed herein do not necessarily state or reflect those of the United States Government or any agency thereof.
\end{abstract}

Prepared by:

Joanne McBrien

Senior Policy Analyst

June 1991

William F. Weld

Paul W. Gromer

Governor

Commissioner of DOER 


\section{INTRODUCTION}

During the 1990/91 heating season, the Massachusetts Division of Energy Resources (DOER) participated in a joint data collection program between several state energy offices and the federal Department of Energy's (DOE) Energy Information Administration (EIA). The purpose of the program was to collect and monitor retail and wholesale heating oil and propane prices and inventories from October, 1990 through March, 1991.

This program augmented the existing Massachusetts data collection system and served several important functions. The information helped the federal and state governments to respond to consumer, congressional and media inquiries regarding propane and No. 2 heating oil. The information also provided policy decision-makers with timely, accurate and consistent data to monitor current heating oil and propane markets and develop appropriate state responses when necessary. In addition, the communication network between the states and the DOE was strengthened through the program.

This final report begins with an overview of the unique events which had an impact on the reporting period. Next, the report summarizes the results from the residential heating oil and propane price surveys conducted by DOER over the $1990 / 91$ heating season. The report also incorporates the wholesale heating oil and propane prices and inventories collected by the EIA and distributed to the states. 
Finally, the report outlines DOER's use of the data and responses to the events which unfoided during the 1990/91 heating season.

OVERVIEW

A. OPEC'S July 1990 Accord

At the end of July 1990, OPEC members reached an agreement to limit oil production in hopes of raising OPEC crude oil prices from about \$15-16 per barrel to a $\$ 21$ per barrel minimum reference price. In the meetings, Kuwait and the United Arab Emirates agreed to stop overproducing and adhere to OPEC's assigned production quotas. Prior to this, Iraq had been concerned that Kuwait's overproduction had contributed to depressed OPEC crude prices.

A few weeks before the OPEC meeting, U.S. West Texas Intermediate (WTI) crude prices started climbing, based on rumors that OPEC would reach and enforce a new production reduction agreement. WTI crude prices increased from approximately $\$ 16.50$ per barrel in June to approximately $\$ 21.50$ by August 1, 1990. (Although U.S. oil inventories were at an historic high level of 392 million barrels at the end of July 1990, crude oil prices increased because the cost to replace the crude oil inventories increased during that period.) Since petroleum product prices are linked to crude oil prices, heating fuel prices were expected to increase when the seasonal demand picked up. Before any significant heating fuel price increases could be solely attributed to the increase in 
crude oil prices, Iraq invaded Kuwait.

\section{B. Iraqi Invasion of Kuwait}

Despite the OPEC agreements, tensions continued to exist between Iraq and Kuwait. Iraq alleged that kuwait had siphoned off Iraqi underground oil supplies and wanted Kuwait to give up part of the Roumeilla oil fields in Kuwait, which lie just east of the Iraqi border. Iraq further charged that kuwait had caused Iraq to lose millions of dollars in oil revenues because Kuwait's overproduction of oil had depressed world crude oil prices, and demanded $\$ 14$ billion in repayment. Efforts by Egyptian and Saudi Arabian leaders to appease Iraq's leader and settle the dispute failed when Iraqi officials walked out of negotiation talks held in Saudi Arabia on August 1, 1990.

Early in the morning of August 2, 1990, Iraq invaded Kuwait. The invasion sent the world crude oil market into turmoil because the invasion immediately interrupted Kuwait's crude oil and refined product production and exports. Also, Iraqi oil supplies were shut off as the United States and certain European countries immediately instituted a boycott of Iragi oil. The United Nations also endorsed a boycott. These actions removed approximately 4.3 million barrels of crude oil per day from world markets.

On the world oil markets, there were concerns that Iraq would invade Saudi Arabia and cut off the Saudi oil supplies. Such a move would have had monumental adverse consequences, 
since any significant supplies of replacement oil into the world oil markets would come from Saudi Arabia.

Many countries subsequently attempted to secure barrels of spot (non-contracted) crude oil on the international markets. However, producing countries such as Mexico reported that they were near maximum output and could not provide additional crude oil to offset the shortfall.

In addition, the prospects for significant refined product imports into the United States were dim because soaring product prices in Europe attracted the available surplus of international refined products.

As a result, there was considerable concern regarding the adequacy of oil supplies, which led to panic and speculation buying, which in turn pushed crude oil prices higher. In mid-August, the United States started to implement short-term measures aimed at inducing petroleum conservation, and increasing oil supplies from Alaska and the Naval Petroleum Reserve. Member countries involved in the International Energy Agreement began similar conservation actions. In late August 1990, OPEC approved a temporary increase in production to cover replacement output for embargoed Kuwaiti and Iraqi supplies.

However, it was estimated that the replacement oil would not reach the market until mid-November, 1990. In addition, rumors persisted that the replacement crude oils would not be of satisfactory quality to replace the lost Kuwaiti and Iraqi 
oil. Uncertainty in the oil markets thus continued, leading to ever-increasing prices.

Throughout september, U.S. refinery utilization rates remained high (at abovi $92 \%$ ), as refiners delayed planned maintenance to ensure adequate petroleum supplies. (Refinery utilization usually declines in the september-october and February-April time periods for switchovers and maintenance.) Still, concerns mounted regarding the ability of refiners to continue to operate at near capacity for an extended period of time. Such concerns were heightened by the fact that a large refinery accident, transportation problems, or bad weather could greatly hamper the already impaired functioning of petroleum markets.

Due to the combination of the above factors, U.S crude oil prices rose until mid-October when they peaked at $\$ 41$ per barrel -- an increase of $\$ 19.50$ per barrel from August 1, 1990 , and an increase of $\$ 24.50$ per barrel from mid-June.

As crude oil prices peaked, refiners became more reluctant to continue to buy high price spot crude oil supplies. In addition, petroleum product demand had eased due to the increasing price of petroleum products and a warmer-than-normal Fall. Refiners began to rely more on their crude oil inventories, taking some pressure off worla oil production and prices. Panic buying began to wane as additional crude oil supplies started to appear on the world market, thus easing the 4.3 million barrel per day gap left by 
the embargo of Kuwaiti and Iragi oil supplies.

Although oil price fluctuations continued due to extreme political uncertainty in the Gulf and the fear of war, beginning in October, market supply and demand fundamentals, began to drive oil prices down. In late November, the United Nations Security Council approved the use of force against Iraq if Iraq did not leave Kuwait by January 15, 1991. At the time, since the crisis was expected to end peacefully, the oil markets did not react in an upward manner. (The markets did not want to be caught with huge petroleum surpluses should the resolution occur at a time when winter demand was falling.)

Just before the January 15 th deadine approached, crude oil prices started to increase. (Some analysts had predicted that oil would go to $\$ 50-60$ a barrel if war broke out.) on January 16, 1991, with no prospects of a peaceful solution, the U.S., with its allies, began a massive air attack against Iraq's military posts.

Surprisingly, crude oil prices collapsed within hours after the war began, due to great early success for the U.S. and its allies, which created expectations of a short war. The "war premium" factor which had inflated prices was gone, and supply of oil was adequate. After launching U.S. military forces, Fresident Bush ordered a $33.8 \mathrm{million}$ barrel sale of crude oil from the strategic Petroleum Reserve (later reduced to about 17 million barrels) and ordered the Treasury secretary 
to waive provisions of the Jones Act which require only the use of United States ships to move oil between United States ports. This strategy further increased crude oil supplies.

\section{Warm Winter Weather}

Prior to the heating season, many forecasters had been predicting a colder-than-normal winter. In preparation, distillate inventories were increased. Many oil marketers recalled having inadequate heating oil supplies during the cold snap of December 1989. Unexpectedly, the weather was extremely warm in the Fall. In mid-October 1990, population-weighted degree days for Boston, Massachusetts were $43 \%$ below those of October 1989, and $35 \%$ below normal. Temperatures continued to be higher than normal throughout the winter.

\begin{tabular}{|c|c|c|c|c|c|}
\hline July 1 - & $\begin{array}{l}\text { Boston, } \\
\text { Degree Days }\end{array}$ & $\begin{array}{l}\text { Massachi } \\
1989-90 \\
\end{array}$ & $\begin{array}{l}\text { ts } \\
\text { Normal }\end{array}$ & $\begin{array}{c}1990 \\
\text { VS } \\
1989 / 90 \\
\end{array}$ & $\begin{array}{l}1990 \\
\text { vs } \\
\text { Normal }\end{array}$ \\
\hline $\begin{array}{ll}\text { October } & 13 \\
\text { November } & 3 \\
\text { November } & 17 \\
\text { December } & 1 \\
\text { December } & 15 \\
\text { January } 5 \\
\text { January } 19 \\
\text { February } 2 \\
\text { February } & 16 \\
\text { March } 2 & \\
\text { March } 16 & \end{array}$ & $\begin{array}{r}127 \\
346 \\
584 \\
852 \\
1200 \\
1747 \\
2246 \\
2749 \\
3132 \\
3510 \\
3882\end{array}$ & $\begin{array}{r}224 \\
441 \\
659 \\
1107 \\
1689 \\
2536 \\
2941 \\
3326 \\
3740 \\
4212 \\
4563\end{array}$ & $\begin{array}{l}195 \\
461 \\
711 \\
1036 \\
1446 \\
2155 \\
2645 \\
3149 \\
3641 \\
4099 \\
4502\end{array}$ & $\begin{array}{l}-43 \% \\
-22 \\
-11 \\
-23 \\
-29 \\
-31 \\
-24 \\
-17 \\
-16 \\
-17 \\
-15\end{array}$ & $\begin{array}{l}-35 \% \\
-25 \\
-18 \\
-18 \\
-17 \\
-19 \\
-15 \\
-13 \\
-14 \\
-14 \\
-14\end{array}$ \\
\hline
\end{tabular}


SURVEY RESULT

Crude oil Prices

Crlide oil prices were about $\$ 21.50$ at the end of July. After the August 2, 1990, Iraqi invasion, crude prices climbed steadily. By mid-October, U.S. spot WTI crude oil prices reached $\$ 41$ per barrel. With the warm weather, an economic downturn, and a drop in demand for petroleum products, crude prices started to ease even though the "war fear" still existed. By the beginning of December, crude prices settled around $\$ 27$ per barrel. Crude prices did not increase again until January 1991, just before the U.S. commenced the war against Iraq. Crude prices jumped on the spot market from $\$ 27$ per barrel to $\$ 32$ per barrel right before the war. After the war began, it appeared that the allied forces would win the war within a short time. U.S. spot crude oil prices fell overnight on January 16 th, from $\$ 32$ per barrel to $\$ 21.50$ per barrel on January 17 th. Crude prices did increase to about $\$ 25$ per barrel for a few days in late January, but fell back and settled at about $\$ 20$ per barrel through March. (See Graph 1.)

Wholesale Heating oil prices

A key determinant of wholesale heating oil prices is the price of crude oil. Wholesale heati:lg oil prices rose $8 \not \subset$ per gallon from mid-June to August 1 based on the $\$ 5$ per barrel increase in crude oil prices after the July OPEC accord. The wholesale price increased from $52 \not \subset$ per gallon to $60 \not \subset$ per 
gallon. After the Iraqi invasion, wholesale prices peaked at $\$ 1.09$ per gallon in mid-october. The total increase in wholesale prices was $57 \not$ per gallon from mid-June to mid-October. Prices then fell through the survey period and were $70 \not$ per gallon by mid-March. This was a drop of $39 \not$ per gallon from the peak of $\$ 1.09$ in October. (See Table 1).

\section{Retail Heating oil Prices}

Typically, retail heating oil prices increase in the Fall, peak in December/January, and decrease in the spring as demand wanes. This heating season, prices ran contrary to normal trends.

In mid-June, retail heating oil prices were about $92 \not$ per gallon. They dipped $2 \not$ per gallon by the end of July, but started rising immediately after the Iraqi invasion. By mid-october, retail heating oil prices were $\$ 1.36$ per gallon -an increase of $46 \notin$ per gallon from July. The Massachusetts statewide average for residential heating oil prices dropped every week after mid-october (with one notable exception in mid-January 1990) throughout the remaining survey months. On the final survey date, March 18, 1991, the residential heating oil price was $\$ 1.05$, a drop of $31 \not$ per gallon from the mid-October price. (See Table 1.)

Interestingly, although wholesale prices set the overall seasonal trend for retail prices, wholesale prices tended to fluctuate more quickly and more widely than retail prices. 
For example, the median decrease in wholesale prices from week to week during the heating season was $4.8 \not \subset$ per gallon, with the smallest one week decrease at $.4 \not$ per gallon and the greatest at $14.3 \not \varnothing$ per gallon. The retail price median decreases week to week were only $3.6 \notin$ per gallon with decreases ranging. from $2.5 \not \subset$ per gallon to $6 \notin$ per gallon. (See Table 2.)

\section{U.S. Crude 0 il Inventories}

U.S. crude oil inventories at the end of July 1990 were at an historic high level of 392 million barrels. After the August invasion, inventories were dropped steadily until the first week in January 1991, when domestic crude inventories hit 326 million barrels. (This level still left a cushion of 26 million barrels above the minimum operating level.) Crude oil inventories started to increase in early February, and reached 341 million barrels by mid-March.

At the end of July, crude oil imports were averaging about $6.6 \mathrm{million}$ barrels per day. By mid-October, imports were down to $5.0 \mathrm{million}$ barrels per day. Imports fluctuated around 5.0 million barrels per day until mid-February when they climbed to 5.6 million barrels per day. 


\section{U.S. Distillate Inventories}

U.S. distillate inventories (including heating oil) had been building throughout the summer and were at approximately 119 million barrels at the beginning of August -- $4 \%$ higher than levels the previous year. During the Kuwaiti invasion, concerns were about gasoline supplies because gasoline inventories ware low and the "driving season" continued through September. The domestic refiners geared up to produce more gasoline.

In the refining process, distillate oil was also produced so that U.S. distillate inventories reached 138 million barrels by the end of October -- an increase of $15 \%$ over the previous year. The fear of another "price spike" in heating oil similar to the one in December 1989, also led to the distillate inventory increases. U.S. distillate inventories started to be drawn down in early November. Inventories fell throughout the winter months and by mid-March they were about 98 million barrels -- a normal level for the Spring.

\section{New England Distillate Inventories}

Inventories of heating oil in New England and on the East Coast were higher this heating season than the previous year. In October, New England distillate inventories reached 10.7 million barrels, -- $13.8 \%$ higher than the previous 
October's 9.4 million barrels. On the East Coast, where most heating oil is consumed, inventories in October were 65.4 million barrels, $26.5 \%$ higher than in October 1989 .

Throughout the heating season, New E.rgland distillate inventories averaged higher than the previous year. However, in March 1991, inventory levels at $3.7 \mathrm{million}$ barrels reacheo. a record low level for that time of year. (See Table 3.)

\section{Massachusetts Heating OiI Demand}

Heating oil demand typically is a function of supply, price and the weather. Although supply was adequate throughout the heating season, the combination of higher prices due to the Gulf war and extremely warm weather resulted in low demand.

\section{Massachusetts No. 2 Fuel Oil Demand \\ (thousands of gallons)}

\begin{tabular}{lrrrrr} 
& \multicolumn{1}{c}{1987} & $\underline{1988}$ & $\underline{1989}$ & $\underline{1990}$ & $\underline{1991}$ \\
January & 231,469 & 229,518 & 251,961 & 232,447 & 182,946 \\
February & 258,109 & 194,339 & 251,626 & 222,408 & 136,072 \\
March & 189,706 & 145,371 & 202,041 & 166,666 & 145,864 \\
Apri1 & 115,761 & 99,691 & 134,749 & 113,227 & \\
May & 73,986 & 77,715 & 77,782 & 83,623 & \\
June & 59,734 & 52,187 & 61,192 & 62,139 & \\
July & 64,339 & 49,490 & 51,264 & 55,508 & \\
August & 61,570 & 46,138 & 48,438 & 81,952 & \\
September & 63,265 & 48,507 & 58,530 & 57,609 & \\
October & 112,338 & 85,488 & 75,796 & 71,126 & \\
November & $i 54,772$ & 113,482 & 150,100 & 115,731 & \\
December & 248,664 & 227,999 & 257,257 & 130,047 &
\end{tabular}


Retail and Wholesale Propane Prices

Like other heating fuels, propane usage is much heavier in the winter than the Summer. Consequently, inventories are built up in April through october, and propane is stored until it is needed.

This August, however, U.S. propane inventories at the primary level were well below the previous year's levels. According to DOE's Energy Information Administration, U.S. inventories of propane at the end of August 1990 were 53 million barrels, compared to 60 million barrels a year earlier. Propane inventories in August 1990 were the lowest for that month in 20 years.

DOE cited several reasons for the low primary inventory levels. First, large volumes of propane were being stored in the Midwest by farmers who intended to use the propane in october for crop drying. Second, the crude oil price increases in July resulted in higher prices for ethane, butane and naptha, traditionally the competing products to propane for use as petrochemical feedstocks. Petrochemical companies, therefore, were purchasing propane for feedstocks. Third, there was speculation that propane was being moved into the secondary and tertiary levels, as retailers and consumers opted to fill storage early having learned from last year's experience.

Unfortunately, tnere was little data available about the actual amount of propane being stored by the petrochemical companies or how much was being held in secondary and tertiary 
storage. The lack of information led to confusion on the propane markets. Some people believed that the diversion of propane by the petrochemical companies from the heating fuels market was keeping residential retail propane prices up. Additionally, many people thought that the combination of low primary inventory levels and increasing prices of propane fuel posed the possibility of significant problems for the winter if a cold snap occurred.

Uncertainty in the propane market continued after tiie Iraqi invasion of Kuwait. After the invasion, spot propane prices increased because propane prices were affected by crude oil prices. (Propane is produced obth by natural gas processing plants and by oil refineries. At refineries, propane is produced along with gasoline, distillate fuels and other fuels.)

Retail propane prices behaved somewhat differently than retail heating oil prices. Throughout most of the survey period, one company consistently charged the highest retail propane price, $\$ 1.90$ per gallon. Similarly, another company charged the lowest price, at $\$ 1.08$ per gallon. The average peaked at $\$ 1.33$ in mid-November and gradually decreased throughout March. It settled around $\$ 1.20$ per galion by the end of the survey period. (See Table 4.)

The retail weighted average price did not show dramatic fluctuations, unlike No. 2 heating oil. The reason is that the propane industry differs from the heating oil industry. 
Typically, propane dealers contract with suppliers a month in advance for firm supply and price commitments. Home heating oil dealers, on the other hand, can pick up oil daily from the terminals and pay that day's price.

Normally, residential propane companies that deliver to residential customers own the residential tanks and regulators. The price of propane also includes costs for tank and regulator maintenance. If the propane customer wants to switch propane companies, the customer must have his/her propane tanks physically changed. Customers do not often do this at every price change. The No. 2 heating oil customer, on the other hand, generally owns his/her own tank, pays only for the oil, and can shop around for a different retailer.

$$
\text { Prior to this heating season, some propane companies }
$$

contracted for high-priced propane in anticipation of inadequate supplies to meet demand. Other companies waited. Even though the the wholesale price of propane fell in October, some companies continued to pass on the cost of the higher-priced contract propane. New England propane supplies remained adequate to meet demand. (See Table 5.)

\section{MASSACHUSETTS' ACTIONS}

The information collected through this program helped DOER to respond to requests from the general public, the media and government entities requested of DOER; helped to identify potential market problems; and helped DOER to update its energy emergency plans and implement some voluntary measures in the 
plan.

\section{Information Dissemination}

After the invasion of Kuwait, retail petroleum prices increassed dramatically. DOER conducted weekly retail price surveys to gather up-to-date information. This information was used to answer numerous consumer complaints, as well as media and legislative inquiries. Since the media constantly needed current information, DOER faxed the weekly survey results to television and radio stations and newspapers for rapid dissemination.

In addition to publishing the weekly survey results, DOER also established a toll-free hotline so that consumers could call for current retail gasoline and heating oil information; published and distributed brochures containing gasoline and heating oil conservation tips, and efficiency tips for consumers of natural gas or oil heating equipment.

Periodic conference calls were made among the New England states' Energy offices. DOER shared its survey results with the other states, and kept them up to date as to the emergency plans DOER had prepared.

In order to monitor petroleum product supplies more closely, DOER increased the reporting requirements of the Massachusetts bulk storage facilities from one end-of-the month report to a weekly report. DOER required information about beginning and ending weekly stocks, weekly terminal receipts, 
the following week's projected receipts, and weekly ending inventory from the previous year. This inventory information, combined with the information provided by EIA allowed DOER to determine if heating oil supplies were adequate.

DOER also used the data collected throughout the heating season to brief the Governor and other appropriate state officials about the energy situation.

\section{Emergency Plans}

After the Iraqi invasion of Kuwait, there was much uncertainty about oil shortages and energy price spikes. In early August, the Commissioner of Energy Resources established an in-house task force to coordinate the gathering of pertinent energy data and to review necessary emergency plans.

As a first step, DOER called in respresentatives of the heating fuel industries to ask them about their plans to meet demand, their supplies, and any problems they might be encountering which DOER could address. In addition, DOER sought their cooperation in continuing efforts to share information. For example, in October, DOER met with a propane industry task force. The task force informed DOER that secondary and tertiary stocks of propane were near $100 \%$ capacity. Propane marketers had urged consumers to fill their tanks early. The propane industry also devised a suggested list of priority customers, and identified steps the industry could take if there was a propane shortage. 
DOER also -..c with Caravan, a Massachusetts non-profit organization designed to encourage transportation fuel conservation through carpooling, vanpooling and other efficient modes of transportation. Together, ideas were developed to encourage consumers to carpool and use public transportation. DOER reviewed and updated the state's emergency plans for each type of fuel and was prepared to implement them, if need be. Voluntary measures inciuded: closing non-essential state buildings heated with No. 2 oil; building temperature restrictions; commercial/industrial fuel switching; and, limiting sales of No. 2 fuel oil. DOER also investigated the possible relaxation of state regulations on permissable sulphur content of fuel.

DOER also updated itsstate set-aside system which would have been implemented in the event of a declaration of an energy emergency by the Governor. Under this plan, DOEk would implement measures to distribute petroleum products to high priority consumers, such as essential services, that were experiencing difficulties in obtaining sufficient fuel supplies. DOER updated these set-aside measures, and prepared the necessary paperwork and reports to implement the program.

\section{CONCLUSION}

The Massachusetts Division of Energy Resources found this joint data collection program to be an integral and important part of energy emergency planning. The consistent 
collection of the data provided an "early warning" system to key decision-makers. Monitoring the trends in the petroleum market also gave DOER the lead time to implement emergency plans, if necessary.

Based on our experience, the propane data collection part of the program could be improved. EIA did not provide wholesale price information which was specific to Massachusetts or New England. The prices were reported as not available. If this was due to restrictions on the dissemination of the information, Massachusetts has confidentiality laws which could protect the data. Next year, DOER requests that EIA provide DOER with the information airectly, if the information cannot be printed in the winter Fuels Report.

A most important element of the data collection program was that DOER was able to establish a more effective communication network with local, regioral, and national oil and propane companies. This network was especially useful when DOER needed to obtain immediate information.

In conclusion, DOER strongly advocates for the continuation of this valuable program. 


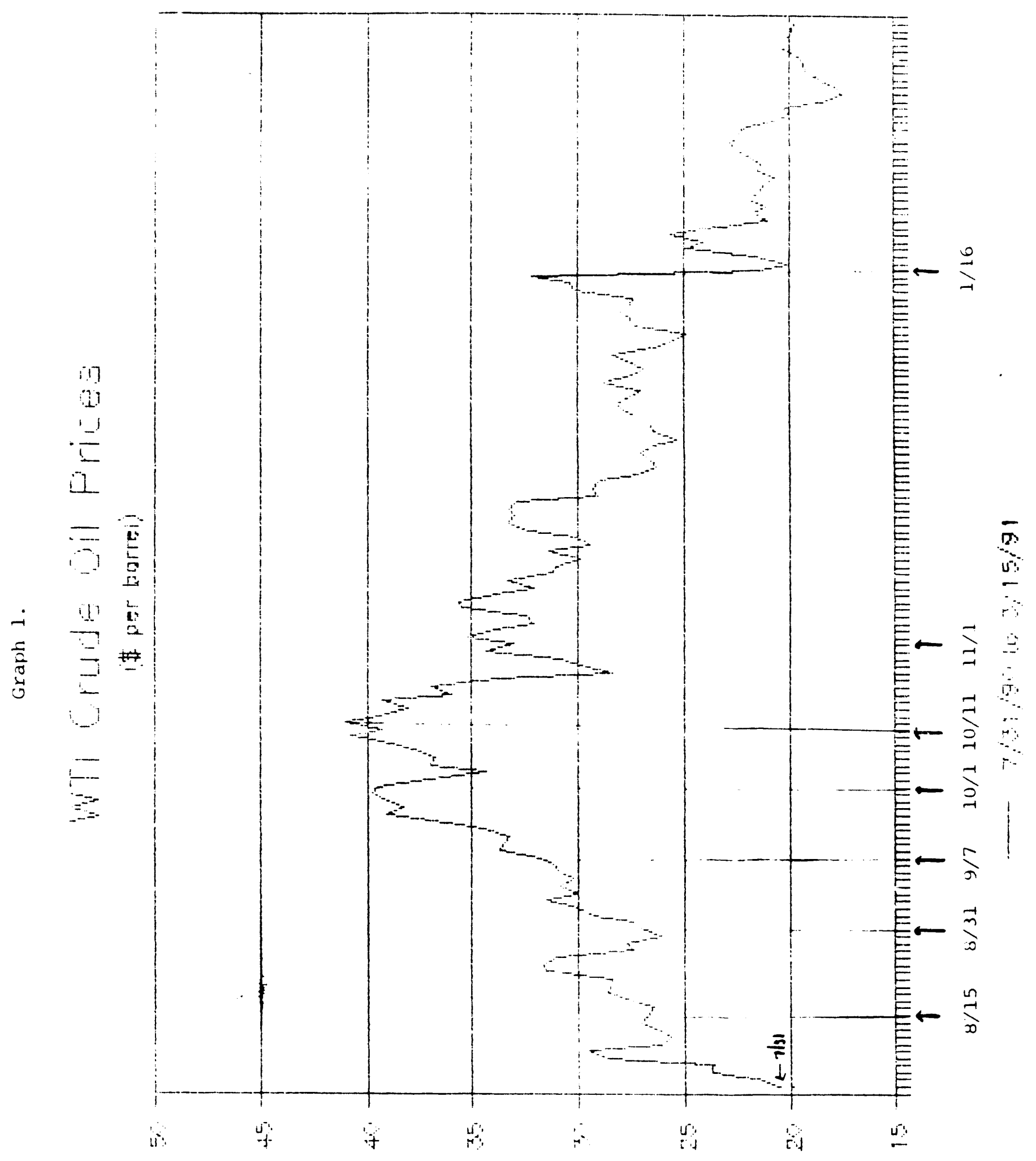

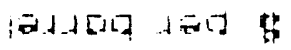


Table 1 .

Massachusetts Retail and Wholesale

Heating oil prices

( $\$$ per gallon)

$\frac{\text { Date }}{1990 / 91} \quad \underline{\text { High }} \quad \underline{\text { Low }} \quad \frac{\text { Straight }}{\text { Average }} \quad \frac{\text { Weighted }}{\text { Average }} \quad \underline{\text { Wholesale }}$ Margin

DOER's survey

\begin{tabular}{|c|c|c|c|c|c|c|}
\hline $\begin{array}{l}06 / 27 \\
07 / 30 \\
08 / 06 \\
08 / 20 \\
08 / 28 \\
09 / 05 \\
09 / 12 \\
09 / 19 \\
09 / 25\end{array}$ & $\begin{array}{r}.999 \\
.999 \\
1.170 \\
1.219 \\
1.319 \\
1.319 \\
1.309 \\
1.309 \\
1.439\end{array}$ & $\begin{array}{r}.689 \\
.739 \\
.840 \\
.949 \\
1.049 \\
1.039 \\
1.079 \\
1.089 \\
1.139\end{array}$ & $\begin{array}{r}.917 \\
.904 \\
.958 \\
1.081 \\
1.184 \\
1.170 \\
1.187 \\
1.194 \\
1.284\end{array}$ & & $\begin{array}{r}.524 \\
.598 \\
.728 \\
.829 \\
.917 \\
.904 \\
.899 \\
.891 \\
1.025\end{array}$ & $\begin{array}{l}.393 \\
.306 \\
.230 \\
.252 \\
.267 \\
.266 \\
.288 \\
.303 \\
.259\end{array}$ \\
\hline \multicolumn{7}{|c|}{ EIA's Survey } \\
\hline $\begin{array}{l}10 / 01 \\
10 / 15 \\
11 / 05 \\
11 / 19 \\
12 / 03 \\
12 / 17 \\
01 / 07 \\
01 / 21 \\
02 / 04 \\
02 / 18 \\
03 / 04 \\
03 / 18\end{array}$ & $\begin{array}{l}1.450 \\
1.449 \\
1.369 \\
1.339 \\
1.339 \\
1.300 \\
1.279 \\
1.299 \\
1.269 \\
1.239 \\
1.199 \\
1.159\end{array}$ & $\begin{array}{r}1.200 \\
1.210 \\
1.099 \\
.999 \\
1.099 \\
1.075 \\
.959 \\
1.059 \\
.959 \\
.935 \\
.845 \\
.775\end{array}$ & $\begin{array}{l}1.314 \\
1.314 \\
1.284 \\
1.301 \\
1.267 \\
1.223 \\
1.186 \\
1.211 \\
1.175 \\
1.148 \\
1.095 \\
1.056\end{array}$ & $\begin{array}{l}1.334 \\
1.362 \\
1.264 \\
1.243 \\
1.254 \\
1.212 \\
1.160 \\
1.208 \\
1.166 \\
1.137 \\
1.089 \\
1.047\end{array}$ & $\begin{array}{r}1.066 \\
1.085 \\
.942 \\
.919 \\
.947 \\
.834 \\
.782 \\
.848 \\
.805 \\
.801 \\
.735 \\
.700\end{array}$ & $\begin{array}{l}.268 \\
.277 \\
.322 \\
.324 \\
.307 \\
.378 \\
.378 \\
.360 \\
.361 \\
.336 \\
.354 \\
.347\end{array}$ \\
\hline
\end{tabular}

Table 2 .

Differences Between

Retail and Wholesale

Heating oil Price Increases/Decreases

( $\$$ per gallon)

\begin{tabular}{|c|c|c|}
\hline$\frac{\text { Date }}{1990 / 91}$ & $\begin{array}{l}\text { Weighted } \\
\text { Average }\end{array}$ & $\begin{array}{l}\frac{\text { Wholesale }}{\text { Average }} \\
\text { Aver }\end{array}$ \\
\hline $\begin{array}{l}10 / 01 \\
10 / 15 \\
11 / 05 \\
11 / 19 \\
12 / 03 \\
12 / 17 \\
01 / 07 \\
01 / 21 \\
02 / 04 \\
02 / 18 \\
03 / 04 \\
03 / 18\end{array}$ & $\begin{array}{l}1.334>-2.8 \uparrow \\
1.362>-9.8 \\
1.264>-2.1 \\
1.243>+1.1 \\
1.254>+4.2 \\
1.212>-5.2 \\
1.160>+4.8 \\
1.208>-4.2 \\
1.166>-2.9 \\
1.137>-4.8 \\
1.089>-4.2 \\
1.047>-\end{array}$ & $\begin{array}{l}1.066>+1.96 \\
1.085>-14.3 \\
.942>-2.3 \\
.919>+2.8 \\
.947>-11.3 \\
.834>-5.2 \\
.782>+5.5 \\
.848>-4.3 \\
.805--.4 \\
.801-5-5 \\
.735--3.5 \\
.700-3.5\end{array}$ \\
\hline
\end{tabular}


Table 3 .

$\frac{\text { New England Distillate Stocks }}{\text { (thousands of barrels) }}$

$\begin{array}{lll}1989 & 1990 & 1991\end{array}$

$\begin{array}{lrrr}\text { January } & 8.6 & 5.4 & 5.4 \\ \text { February } & 5.8 & 4.7 & 5.8 \\ \text { March } & 5.4 & 3.9 & 3.7 \\ \text { April } & 4.7 & 4.0 & \\ \text { May } & 4.6 & 4.4 & \\ \text { June } & 4.5 & 5.0 & \\ \text { July } & 8.2 & 8.8 & \\ \text { August } & 8.8 & 10.1 & \\ \text { September } & 9.2 & 10.8 & \\ \text { OctobPr } & 9.4 & 10.7 & \\ \text { November } & 7.7 & 8.7 & \\ \text { December } & 4.4 & 8.3 & \end{array}$

Table 4 .

Massachusetts Retail propane Prices

and

East Coast Wholesale Propane Prices

Massachusetts Retail Propane Prices

(\$FEs gallon)
East Coast Wholesale Prices
Date

$1990-1991$

$10 / 01$

$10 / 15$

$11 / 05$

$11 / 19$

$12 / 03$

$12 / 17$

$02 / 07$

$01 / 21$

$02 / 04$

$02 / 18$

$03 / 04$

$03 / 18$
High

Low

$\$ 1.089$
1.089
1.089
1.089
1.089
1.089
1.089
1.089
1.089
1.089
1.089
1.060

$$
\begin{aligned}
& \$ 1.900 \\
& 1.900 \\
& 1.900 \\
& 1.900 \\
& 1.900 \\
& 1.900 \\
& 1.900 \\
& 1.900 \\
& 1.900 \\
& 1.900 \\
& 1.900 \\
& 1.830
\end{aligned}
$$

Weighted

Average
$\$ 1.248$

1. 304

1. 328

1. 332

1. 332

1. 317

1. 306

1. 296

1.275

1. 251

1. 225

1. 197
$\$ .648$

.665

.570

.553

.542

.457

.483

.455

.383

.389

.384

.390 
Table 5 .

New England Propane Stocks

(thousands of barrels)

\section{9}

January

February

March

April

May

June

July

August

September

October

November

December

.4

.2

.3

.4

.2

.6

.7

.4

.3

.1

. 3
1990

1991
.2

.1

.3

.1

.2

.5

.3

.1

.4

.4

.6

.5

* less than 500,000 barrels 
RETAIL HEATING OIL AND PROPANE PRICE SURVEYS' METHODOLOGY

In an effort to ensure consistency, the EIA provided the states with the samples of No. 2 heating oil and propane companies to be surveyed for retail prices. The Massachusetts No. 2 heating oil company list consisted of 32 oil dealers throughout Massachusetts. These dealers represented small and large oil companies, and the retail division of major oil companies. Additionally, EIA provided DOER with a lisi of 15 propane dealers. DOER collected retail heating fuel prices from these companies via telephone surveys at specified times during the survey period of October 1, 1990, through March 18, 1991.

DOER transmitted the retail price data within 3-4 work days to EIA via fax machine. The EIA, in turn, calculated a weighted average retail price for heating oil and propane.

For the June - September retail heating oil data, DOER conducted its own retail No. 2 heating oil price surveys. DOER called 80 oil dealers asking for their retail price. The statewide average, however, was a straight average not a weighted average.

EIA conducted the wholesale heating oil and propane price surveys as well as the heating oil and propane stock surveys. EIA aggregated all the information and distributed it to the states in weekly publications. 

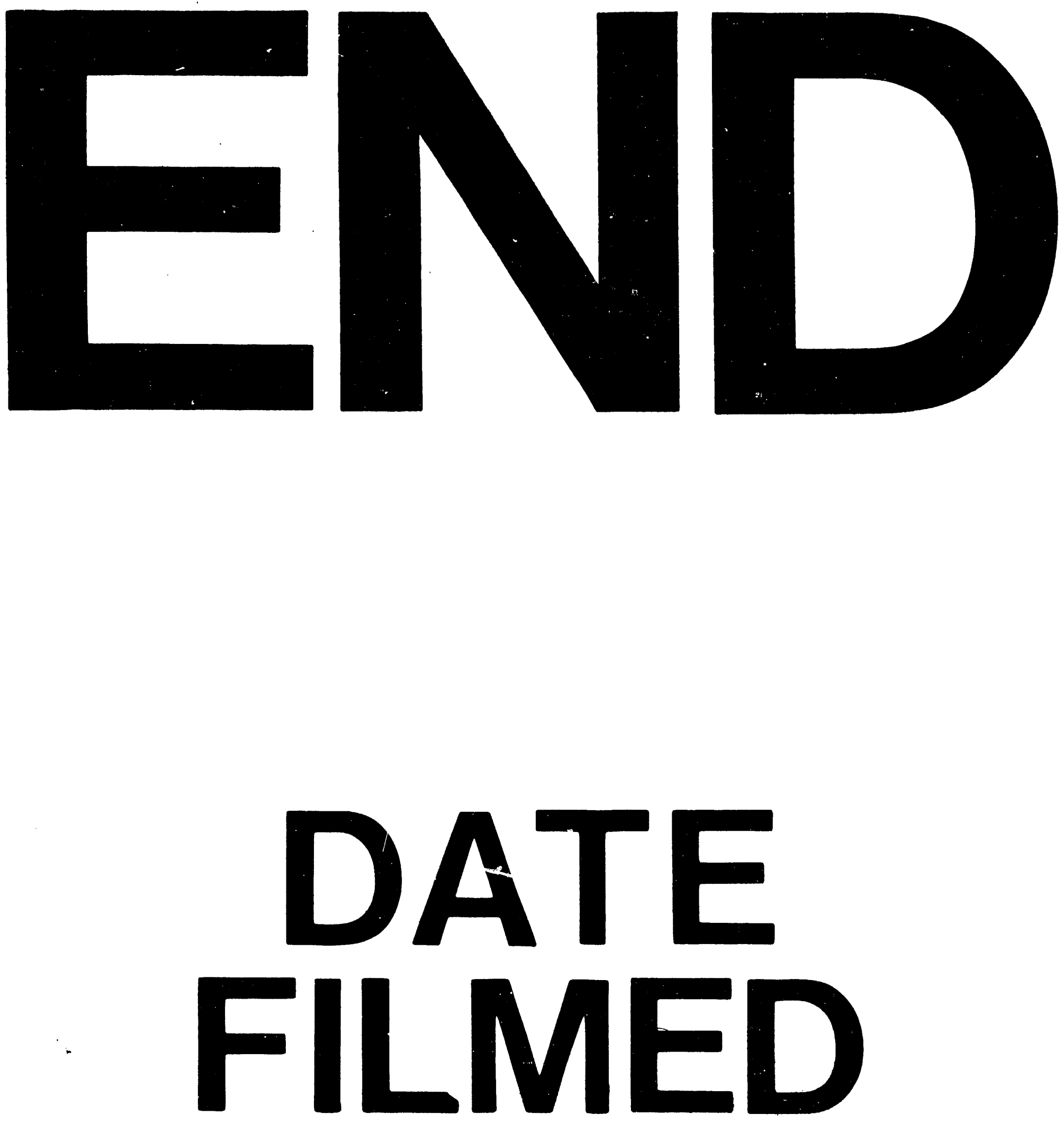

1

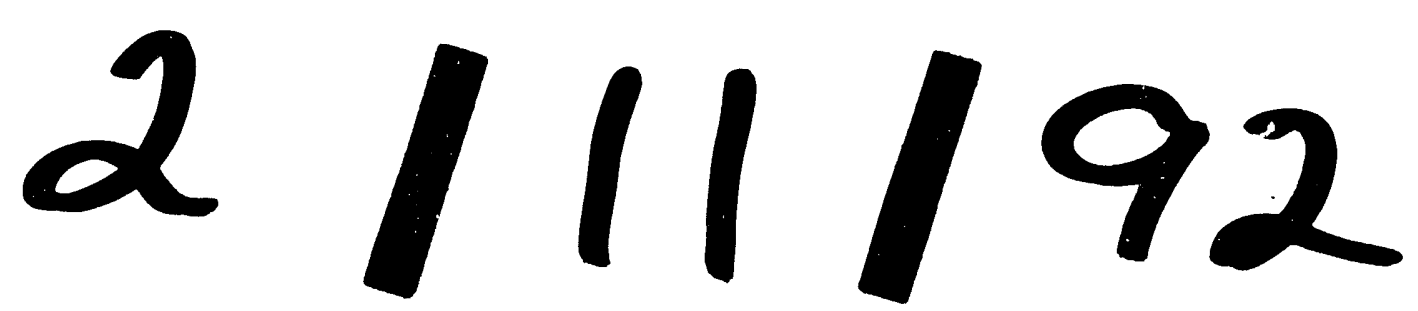

